\title{
Neutralizing Trade-off Effect between Accuracy and Fluency in EFL Writing by Mentor Text Modeling: Cognitive Complexity in Focus
}

\author{
Reza Biria ${ }^{1}$, Farahnaz Liaghat ${ }^{2 *}$ \\ ${ }^{\prime}$ Department of English Language, Isfahan (Khorasgan) Branch, Islamic Azad University, Isfahan, Iran \\ ${ }^{2}$ Department of English language, Department of English Language, Yadegare Imam (RAH) Branch, Islamic Azad University, Tehran, Iran \\ Corresponding Author: Farahnaz Liaghat, E-mail: farahnazliaqat@gmail.com
}

\section{ARTICLE INFO}

\section{Article history}

Received: December 10, 2017

Accepted: January 23, 2018

Published: March 01, 2018

Volume: 7 Issue: 2

Advance access: February 2018

Conflicts of interest: None

Funding: None

\begin{abstract}
The present study sought to explore the efficacy of a brand-new approach to teaching writing called mentor text modeling in neutralizing trade-off effect between accuracy and fluency in writing tasks with different levels of cognitive complexity. To this end, a total of 60 (30 male and 30 female) Iranian EFL learners were randomly selected and assigned to three groups of comparison, each containing 20 (10 male and 10 female) learners. Employing a pretest/posttest experimental design, learners of the three groups received instruction on advanced writing during an 11-week course. At the commencement of the course, the learners' fluency and accuracy in writing were gaged through three writing tasks with high, moderate, and low levels of cognitive complexity. Having been exposed to the same instructional input, the learners of each group underwent writing instructions based on one of three approaches to teaching writing, namely, mentor text modeling, product-based approach, and process-based approach. At the end of the study course, the learners' writing performance was assessed on three tasks parallel to the pretest measures. Results of running correlation analysis indicated that contrary to the two traditional approaches to teaching writing, mentor text modeling was capable of improving accuracy and fluency simultaneously and, as a result, was found to be effective in neutralizing the trade-off effect between accuracy and fluency in writing tasks with high, moderate, and low cognitive complexity levels. The study's finding may urge EFL teachers to include mentor texts while teaching writing to realize a balanced improvement in EFL learners' writing competence.
\end{abstract}

Key words: Mentor Text Modeling, Trade-Off Effect, Accuracy, Fluency, Cognitive Complexity, Writing Competence

\section{INTRODUCTION}

\section{Preliminaries}

Literature on foreign/second language (FL/L2) development includes a plethora of studies assuming writing as the most demanding language learning skill (e.g., Deane et al., 2008; Hayes \& Flower, 1980; Nueva, 2016; Richards $\&$ Renandya, 2002). The endorsement of such assumption, as believed by Al-Haq and Al-Sobh (2010), may lie in the fact that writing calls for a high level of productive control while dealing simultaneously with several interwoven micro-skills such as developing an idea, capturing mental efforts to think out sentences, translating sentences into the target language, and integrating ideas (in the form of sentences) in a meaningful and communicative way. Due to the fact that writing can be viewed as a continuum of activities ranging from the more mechanical or formal aspects of writing down on the one end, to the more complex act of composing on the other end (Omaggio Hadley, 1993), writing tasks' cognitive demands must be taken into consideration while imagining the portrait of problems that writers may face in English as a foreign/second language (EFL/ESL) writing. It is undoubtedly the act of composing, though, which can create problems for students, especially for FL/L2 learners who are writing in academic contexts. Writing in a foreign/second language becomes even more complicated when learners' competence in writing is supposed to be assessed in co-operation with other skills such as reading and listening.

Notwithstanding its challenging nature, writing is considered as one of the most important skills for educational success in the current communication world. Therefore, a conspicuous number of researchers have sought to explore ideas related to EFL/ESL writing instructions. Although, a number of approaches and strategies have been put forth to help EFL learners develop their writing skill, agreement on the most effective ones was not reached to date. Nonetheless, the existing literature on teaching EFL writing over the past half century testifies to the usefulness of adopting either product (e.g., Balakrishnan, 2010; Nordin \& Mo- 
hammad, 2006; Sakoda, 2007) or process (e.g., Rahman, 2011; Onozawa, 2013; Sun, 2009) approaches to teaching writing.

According to Nunan (1999), a product-based approach to teaching writing focuses on the linguistic features, as well as putting emphasis on a proper evaluation of written output based on learners' knowledge of language form. On the contrary, in a process-based approach, as its name implies, the focus is on the steps involved in drafting and redrafting a piece of work such as prewriting, drafting, revising, and editing (Nunan, 1999). The deficiency of the mentioned approaches in placing simultaneous emphasis on both product and process may result in unbalanced L2 writing performance in terms of different linguistic features in writing such as accuracy and fluency (Reid, 2001). To eliminate such an unpleasant outcome called trade-off effect, an innovation in writing instruction through a synthesis of the two traditional approaches (i.e., process-based and product-based) deems noteworthy (Brookes and Grundy, 1990; as cited in Tangpermpoon, 2008).

As their recent attempts to reach an alternative approach to the traditional ones, some researchers (e.g., Escobar Alméciga \& Evans, 2014; Kane, 2012; Naorji, 2012) explored the effectiveness of an approach based on socio-affective strategies in language learning and teaching realm, namely mentor text modeling. The approach generally relies upon the interplay between learners, mentor texts, and instructor to support English communication in EFL/ESL classrooms increasing teacher-student cooperation, feedback, mediation, and collaboration.

\section{Statement of the Problem}

Having admired the theories about the potential impact of mentor text modeling on writing competence, the present study sought to ascertain whether mentor text modeling approach has the potential to be functioned as a holistic approach for the purpose of improving EFL learners' writing ability while working on writing tasks with different levels of cognitive complexity. More precisely, considering assumptions about the deficiency of traditional approaches to teaching writing in placing equal emphasis on both accuracy and fluency, this study aimed at exploring the efficacy of mentor-text modeling, as an alternative to the traditional approaches to teaching writing, in neutralizing trade-off effect between accuracy and fluency in writing tasks with different cognitive complexity levels.

\section{Objectives of the Study}

The chief aim of this study was to scrutinize the capability of mentor text modeling in neutralizing trade-off effect between accuracy and fluency in comparison with the other two prevalent approaches to teaching writing in Iranian EFL writing contexts; product-based and process-based approaches. As its secondary aim, the study explored the relationship between writing tasks' cognitive complexity and the efficacy of mentor text modeling in neutralizing trade-off effect between accuracy and fluency.

\section{Research Questions}

Based on the research goals enumerated above, the study perused the following research questions.

1. Does adopting mentor text modeling approach to teaching writing yields simultaneous development in Iranian EFL learners' accuracy and fluency in writing?

2. Is there any significant interaction between writing tasks' level of cognitive complexity and the efficacy of mentor text modeling in neutralizing trade-off effect between accuracy and fluency?

\section{LITERATURE REVIEW}

\section{Different Approaches to Teaching Writing}

For decades, attitudes toward teaching second or foreign language learning skills in general and teaching writing in particular have been the subject of debate in the education system across the world. The earliest work in teaching writing was based on controlled or guided composition and the usefulness of such a restricted manipulation resulted in the emergence of a specific teaching method called product-based approach. As its name implies, the product-based approach is concerned with the final result of the writing process. It gives priority to classroom activities and asks learners to be engaged in imitating and transforming model texts. Pincas (1984) defined a product-based approach to writing as "being primarily about linguistic knowledge, with focus on the appropriate use of vocabulary, syntax, and cohesive devices" (p. 5). Having recognized four stages in a product-based approach including familiarization, controlled writing, guided writing, and free writing, Pincas (1984) believed that such an approach is thoroughly teacher-centered. Using a model text or imitation is found to be an efficient way through which one can easily learn. Nonetheless, as claimed by White (1988), "what the model does not demonstrate, is how the original writer arrived at that particular product. In other words, it gives no indication of writing process" (p. 6).

During 1970s and 1980s, a paradigm shift occurred in the realm of writing from product to process. The main reason for this change was the idea that each piece of writing has its own history and follows its own developmental path. This partially new trend in writing classes (i.e., process-based approach) primarily regarded writing as a process and de-emphasized writing as a product. Murray (1972) defined the process-based approach as "a teaching approach that focuses on a variety of processes a writer engages in when constructing meaning" (p. 16). The chief objective of such an approach is to make students aware of the cognitive strategies involved in writing, as well as enabling them to gain control over different processes contributing to writing. To highlight the efficacy of the process-based approach, Meyers (2009) stated that "using this approach, learners can make a hierarchical relationship of ideas which helps them with the structure of their texts" (p. 9). Process-based approach is occasionally speculated to be even more effective than product-based approach, inasmuch as it allows students to explore and develop personal approach to writing (Sutikno, 2008). Despite all the mentioned advantages, however, lack 
of a good model, which according to Torghabeh, Hashemi and Ahmadi (2010) can partly eliminate the burden of devising content from the learners, can be seen as an essential drawback to a process-based approach.

While process-based approach has gained favor in ESL/EFL context, some writing instructors question its validity for developing writing skills required to write in academic contexts. In reaction to process-based approach, several ESL writing researchers (e.g., Hestenes, 2006; Lynne \& Cappelli, 2007; Naoroji, 2012; Ortenburger, 2013) carried out studies on an alternative approach, namely mentor-text modeling, focusing on advanced and academic writing tasks designed to teach students how to write a qualified piece of writing. Adopting such an approach to teaching writing, $\mathrm{EFL} / \mathrm{ESL}$ learners are instructed how to imitate mentor text for learning new ways to improve their writing competence. Mentor texts, as stated by Naoroji (2012), "provide concrete examples of what teachers want students to do and help students understand writing in particular genres or formats from the inside out" (p.34). In other words, mentor texts help students imagine the kind of writer they can become, as well as helping teachers move the writer, rather than each individual piece of writing, forward. Having corroborated the mentioned point of view, Orttenburger (2013) asserted that "using mentor-based approach provides learners with a less cognitive complexity, but more emphasis on the writer's craft, structure, and ideas" (p. 1).

Research on writing instruction has demonstrated a positive impact of including mentor texts as essential component of writing classes. Having applied mentor texts in teaching writing to EFL/ESL learners, a great number of researchers concluded that writing achievement improves as a result of encouraging students to analyze and imitate patterns and forms embodied in model texts (e.g., Bogard \& Mackin, 2015; Dorftman \& Cappelli, 2007; Escobar Almeciga \& Evans, 2014; Gallagher, 2011; Graham \& Perin, 2007; Kane, 2012; Pytash \& Morgan, 2014). Nonetheless, no research, to the best of the researcher's knowledge, has been carried out to explore the efficacy of mentor text modeling approach in developing different linguistic components such as accuracy and fluency in writing.

\section{Accuracy and Fluency in Writing}

As a feature of writing performance, accuracy is broadly concerned with the absence of grammatical, morphological, spelling, and punctuation errors in written texts (Polio, 2001). Although accuracy is better measured as function of errors produced, it can be measured either specifically (e.g., accuracy of verb forms) or generally (e.g., overall number of errors or error- free units). Making a firm decision to use either specific or general measures of accuracy is heavily dependent on learners' development sequence (proficiency) as well as task's condition. For research other than focused tasks, Ellis and Barkhuizen (2005) recommended general measures of accuracy such as percentage of error-free clauses or number of errors per 100 words as well as percentage of error-free minimal terminable units (T-units) (Larsen-Freeman, 2009). Another variation of this general measure, total errors per
AS (analysis of speech unit) has already been used as well (Michel, et al., 2007).

Fluency, as defined by Wolfe-Quintero, Inagaki, and Kim (1998), "is not a measure of how sophisticated or accurate the words or structures are, but a measure of the sheer number of words or structure units a writer is able to include in his/her writing within a particular period of time" (p. 25). This view of fluency was regarded in operationalizing the commonly used fluency measures in L2 writing studies such as total number of words, total number of T-units, and total number of clauses produced in a given period of time.

\section{Trade-off Effect between Accuracy and Fluency}

With the emergence of theory-based research during the 2000s, Task-Based Language Teaching (TBLT) began to attract language educators' attention (Kuiken \& Vedder, 2008). Therefore, a great number of empirical studies carried out on task-oriented approaches was mostly focused on exploring the effects of task complexity on learners' L2 performance. Concerning this special issue, the theoretical overview of two most influential models of attention was proposed that prompted extensive research into the effect of task demands on selective attention and co-ordinational resources during dual and multi-task performance. The models were trade-off hypothesis based on the limited attentional capacity model by Skehan (1998), and the triadic componential framework based on cognitive hypothesis by Robinson (2001, 2003, $\&$ 2007). Notwithstanding the two models' agreement on the fact that focusing on one component of language performance may result in a lower performance in one or both of the other components, they make contrasting predictions about the attentional demands and the cognitive processing of tasks in relation to linguistic performance.

Believing the fact that the limited mental capacity of learners during writing process is the result of a single-source view of attention, the trade-off model proposed by Skehan (1998) predicts a tension between meaning (fluency) and form (accuracy and complexity). Having rejected the single-source capacity limitation, Robinson $(2003,2007)$ explained the trade-off effects in language performance through the cognition hypothesis proposing that a more complex task will result in an increase in the complexity and accuracy in the language performance of that task. In an earlier study carried out in 2001, however, Robinson specifically had revealed that in simple monologic tasks, fluency but not complexity or accuracy is likely to be promoted, while in complex monologic tasks, accuracy and complexity but not fluency are promoted.

Trade-off effects among the three components of FL/L2 writing; complexity, accuracy, and fluency (CAF), has attracted adequate attention to date. Several studies researching CAF found trade-off effect, in which a higher performance in one component corresponds to lower performance in another. To support Robinson's cognition hypothesis, a large body of studies has been recently carried out. Michel, Kuiken, and Vedder (2007), for instance, tested the hypothesis and found that the students who perform the more difficult task develop in terms of accuracy; however, their fluency would decrease 
with no significant effect on language complexity. Additionally, Yuan and Ellis (2003) reported an accuracy and fluency trade-off within the careful online planning condition.

\section{Cognitive Complexity Models}

Among various models proposed to categorize different levels of cognitive complexity, the models proposed by Bloom (1956, 2001) and Webb (1997) are of paramount importance. The model proposed by Bloom (2001) is a revised form of the original Bloom's Taxonomy (1956) which identifies six levels within the cognitive domain ranging from the most simple to the most complex including remembering, understanding, applying, analysis, evaluating, and creating. Bloom's Taxonomy is difficult to use, inasmuch as it needs an inference about the skill, knowledge, and background of the students who respond to the task.

In 1997, Webb developed a criteria for analyzing the alignment between standards and standardized assessments. This model offers the Depth of Knowledge (DOK) that is used to analyze the cognitive expectation demanded by standards, curricular activities, and assessment tasks. The rational for classifying tasks/items by Webb's level of complexity is to focus on tasks' demands instead of students' ability. The adapted version of the Webb's (1997) model includes four ascending levels in terms of cognitive complexity including recall, basic application of skills and concepts, strategic thinking, and extended thinking (complex reasoning). Actually, the Webb's (1997) model is based on content complexity which essentially considers factors such as prior knowledge, processing of concepts and skills, sophistication, number of parts, and application of content structure needed to get the result. In contrast to content complexity that refers to the cognitive demands inferred from the language of a standard content, cognitive complexity refers to the cognitive demands that standards and corresponding instructions impose upon the learners.

In 2008, Florida Department of Education adapted Webb's (1997) four-level DOK model of content complexity to assess the Florida Comprehensive Assessment Test (FCAT) results and developed a three-level (high, moderate, and low) model of cognitive complexity. To this end, the first two levels of Webb's model represented in Florida's adaptation of Webb's DOK model as low and moderate, respectively. DOK Levels 3 and 4 were collapsed into a single, "high" DOK level as critical and strategic thinking.

Considering the significance of writing tasks' cognitive complexity on learners' writing performance (Hamp-Lyons \& Mathias, 1994; Robinson, 2001), one pedagogical challenge is how any given innovative pedagogical intervention (e.g., mentor text modeling) can be adjusted for writing tasks with different cognitive complexity. Therefore, it can be claimed that studies on mentor text modeling have not resulted in defensible, robust, and conclusive findings regarding the capability of such an approach to neutralize the trade-off effect between accuracy and fluency in writing tasks with different cognitive complexity.

\section{METHOD}

\section{Operational Definitions of the Study Variables Writing tasks' cognitive complexity levels}

As a structure for identifying the alignment of the cognitive demands that different types of writing tasks would place on the participants, the Florida's original three-level model of low, moderate, and high with some minor modifications suited the current study's needs. To this end, the two first levels in the Florida's original model (i.e., low and moderate levels), which according to the Webb's (1997) DOK model corresponded to 'recall' and 'basic application of skills and concepts' respectively, was considered as low complexity level, whereas, the last level (i.e., high) referred to 'strategic thinking, extended thinking, and complex reasoning' was split into two separate levels as moderate (strategic thinking) and high (extended thinking and complex reasoning) levels. To fulfill the study's objective, three types of writing tasks commonly used in assessing L2 learners' writing skill; namely, independent writing tasks, integrated writing tasks, and analytical writing tasks, were assigned to the three different levels speculating that cognitive demands in writing increase incrementally from independent writing task (low) to integrated writing task (moderate), and finally, to analytical writing task (high).

\section{Accuracy measure}

In agreement with what has been operationalized in a vast body of task-based research on different writing qualities (e.g., Ahmadian \& Tavakoli, 2011; Yuan \& Ellis, 2003) and concerning the learners' English proficiency (upper-intermediate to advanced), the present study used the most prevalent measure of accuracy defined as the ratio of error-free T-units to total T-units $(\mathrm{EFT} / \mathrm{T})$. Following the view expressed by Ellis and Yuan (2004) the term "error" was operationalized as any deviation in syntax, morphology, and lexical choice.

\section{Fluency measure}

To judge the participants' fluency in writing, "text length", which is measured as the total number of words used in a given time span, was used. As believed by Wolf-Quintero et al. (1998), this index is a useful fluency measure and is more valid than the other measures such as total number of T-units or clauses (Polio, 2001). Given to the fact that all types of writing tasks employed in the current study were time-limited, the total number of words used in each essay was used as the working definition in measuring fluency.

\section{Participants}

A total of 60 male and female (30 male and 30 female) EFL learners from an English teaching institute located in Tehran, Iran, constituted the participants of the study. Employing stratified random sampling method, the participants were selected from among 98 male and female Iranian candidates of IELTS, TOEFL, and GRE tests. All the participants had 
studied English solely within the educational system of Iran and none of them had the experience of studying or living in English-speaking countries. The participants' English proficiency was estimated to be at upper intermediate to advanced level based on the results of a placement test administered by the institute prior to the study course. Nevertheless, a quick version of the Oxford Placement Test (QPT) was administered to all the participants and the results were used in forming three homogeneous groups of participants, each containing 20 EFL learners (10 males and 10 females). The groups were then randomly assigned to three comparison groups, namely, product-based, process-based, and mentor-based groups.

\section{Instruments}

\section{Quick placement test (QPT)}

The QPT designed in collaboration with the University of Cambridge ESOL Examinations (UCLES) is a quick version of the Oxford Placement Test (OPT). The test, including 60 multiple-choice questions in two parts was administered prior to the course to guarantee the participants' homogeneity in terms of English proficiency level. As asserted by Geranpayeh (2003), the test has been validated in 20 countries administering to more than 6,000 students. Nonetheless, the reliability index of this test was checked using K-R21 formula and the coefficient was found to be acceptable (.79).

\section{TOFEL iBT practice tests of written English}

Two different TOEFL iBT practice tests of written English, extracted from the actual TOEFL corpus, were served as the pretest and posttest in the current study. The most recent revision of the TOEFL iBT test (launched in 2005) contains two different writing tasks; namely, the independent task and integrated task. Quite similar to the TOEFL test's actual setting, on an independent writing task the learners were given a specific topic and they were asked to write an essay on the topic in 30 minutes. The integrated task, however, required the learners to read, listen, and then write in response to what they had read and heard. Before writing the integrated essay, the participants had 3 minutes to read a passage on an academic topic. They, then, listened to a lecture excerpt while they were allowed to take notes during the lecture. Finally, the learners were given 20 minutes to plan and write an essay summarizing the lecture, as well as comparing it to the reading passage. The validity and reliability of both the pre- and posttest is self-evident considering the vast body of research carried out to investigate the Reliability and Comparability of TOEFL iBT Scores (see TOEFL iBT Research Insight, published by ETS, for the reliability and comparability of TOEFL iBT scores).

\section{GRE analytical writing practice tests}

In addition to the TOEFL independent and integrated writing tasks, two analytical writing practice tasks, selected from the GRE test corpus, examined the participants' analytical writing skill and critical thinking before and after the study course. The analytical writing measure included two separately timed analytical writing tasks, namely Analyze an Issue and Analyze an Argument. The Analyze an Issue task assessed the participants' critical thinking ability, as well as examining the way they expressed their thoughts about a topic of general interest in writing. The Analyze an Argument task, on the other hand, assessed the participants' ability to understand, analyze, and evaluate arguments according to specific instruction. The allocated time span to accomplish each of the two tasks involved in the GRE analytical measure was 30 minutes.

\section{Materials}

A total of six writing tasks including two TOEFL independent writing practice tasks, two TOEFL integrated writing tasks, and two GRE analytical writing (both argument and issues) tasks were constituted the core instructional materials of the study course. To maximize the input authenticity, all writing tasks were chosen from the two latest corpus of TOEFL and GRE real tests, namely Official TOEFL iBT Tests (Volume 1, Second Edition) and The Official Guide to the GRE revised General Test.

\section{Procedure}

To guarantee the homogeneity of the study groups in terms of English proficiency, the QPT was administered to the participants and the results was utilized to form three comparison groups, each containing 10 male and 10 female learners. To this end, after ranking the participants based on their scores, the first male and female participants with highest score were assigned to one group and the two subsequent pairs with the second and third highest scores were assigned to the other two groups. This process continued to the ones with the lowest scores.

As the initial step toward administering the study treatment, all the participants were pretested on both the TOEFL writing practice tasks (independent and integrated) as well as the GRE analytical writing tasks (issue and argument). The participants' writings were then analyzed individually by two different raters evaluating the fluency and accuracy measures. The strong correlation between two sets of scores elicited by the two raters (fluency: $r=.732, p<.001$; accuracy: $\mathrm{r}=.776, \mathrm{p}<.01)$ indicated an acceptable degree of inter-rater agreement. Having been pretested in writing proficiency, all the participants received over 26 hours of instruction during an 11-week course on advanced writing. The groups' member met each other twice a week and each session lasted 90 minutes. During the study course, all three groups were exposed to the same authentic language input (a total of six writing tasks with different levels of cognitive complexity). The only distinction among the three groups was the approach adopted to teaching writing. After completion of the study treatment and throughout the last two sessions of the course, the learners were given a posttest parallel to the pretest to assess any changes in their writing proficiency as the results of the study course. The sections 
that follow elaborate on different types of writing instruction implemented in the three study groups.

\section{Writing instruction based on mentor text modeling}

To adopt mentor text modeling approach, the learners in the mentor-based group were initially provided with mentor texts at the commencement of training. To this end, the sample essays written by the most qualified test takers (rated by ETS using a score of 6 out of 6 for GRE tasks and a score of 5 out of 5 with regard to TOEFL tasks) were used as the mentor texts. Having been provided with a mentor text, the learners were asked to meticulously read the text two times; first individually and second in collaborative groups. Subsequently, the instructor read the text aloud and periodically stopped and highlighted specific elements of the writing, such as transitional phrases, important vocabulary words, and statistics that reinforced the author's argument (if any). During the instruction, the instructor covered particular elements of writing including punctuation for emphasis (bullet points), word choice (jargon and specific vocabulary), structure of the argument (thesis, counterarguments), and transitional words (first, second, in addition to, finally, furthermore). When discussing the mentor text's details, the instructor also highlighted how the author used a variety of examples to support his/her claims. In the cases which statistics were included in the mentor texts, the instructor attracted the class specifically to examine the data author used to support his/her claims, as well as discussing how statistics can be presented to alter or steer an argument in a particular direction.

After fully analyzing the mentor text by the instructor, she tried to lay the foundations for learners' active engagement asking specific questions such as "What does this sentence do?" and "What would be the author's chief intention when shifting the text's rhetoric?". The instructor then invited the learners in a class discussion about the mentor text. Working in collaborative learning groups, the learners discusses their thoughts and ideas about the mentor text as well. Afterwards, the learners were required to do the given writing task by themselves. They spent a short period of time sharing their writing with the class. Finally, the instructor conducted learner-instructor conferences discussing how successful were the written texts in possessing the mentor text's qualities.

\section{Product-based writing instruction}

The most traditional approach to writing, a product-oriented approach, was regarded in teaching the learners of the product-based group. As the first stage of instruction, a model text representing a sample of the writing task was read to the class. Having highlighted important features of the writing task, the instructor embarked to teach the language structure, lexicon, and general strategies required to accomplish it. After devoting a couple of sessions to over teaching of the grammar, vocabulary items, and conventions required to do the writing task, the learners commenced writing utilizing what they have been taught to produce the final product (essay). Having analyzed the learners' ultimate productions, the instructor rated the learners' writings assigning a letter grade to each one, as well as making brief comments about the required revisions. It is worth noting that the learners of the product-based group were not given any final chance to modify their texts based on the remarks.

\section{Process-based writing instruction}

In the other comparison group (the process-based group), the learners were taught advanced writing employing a process-oriented approach. To this end, the learners were initially divided into five small groups, each containing four learners. The instructor began every session brainstorming the learners' ideas about the overall purpose and structure of any given writing task. The learners were then invited to discuss their opinions on general strategies needed to do the task while the teacher remained in the background during this phase. In fact, the instructor was only providing language support, if required, to avoid inhibiting the learners from expressing their real views. Subsequently, the learners were required to write the first draft of the task in their groups. After completion of the initial drafts, the learners in each group were asked to exchange their texts with each other, so that every learner in the group was reader of one of his team-mate's work. The logic behind shifting the learners' role from a mere writer to a reader was providing them with a chance to develop an awareness of the fact that the essay which is going to be produced by them as a writer will be read and judge by someone else. Finally, the drafts were returned and modifications were made based upon peer feedback and the final draft was written by every learner in groups. The final copies were then exchanged within the groups for proofreading and making the final comments on the essays' edition.

\section{Data Analysis}

To answer the first research question and to investigate the efficacy of mentor-text modeling in neutralizing the tradeoff effect between accuracy and fluency in writing tasks with different levels of cognitive complexity, correlation analysis was carried out to investigate the relationship between fluency and accuracy measures in different groups of the study. Additionally, a detailed comparison of the correlation estimates among different tasks answered the second question posed to ascertain whether the efficacy of mentor-text modeling is dependent on tasks' level of cognitive complexity.

\section{RESULTS}

\section{Descriptive Statistics}

Tables 1 and 2 display the descriptive statistics of the learners' accuracy and fluency scores in the three study groups for writing tasks with different cognitive complexity levels (CCL).

Detailed comparison of the learners' performance on the pre and posttest measures, as demonstrated in Table 1, showed a substantial increase from the pretest to the posttest 
in all three groups of the study for writing tasks with high, moderate, and low CCL. However, the greatest amount of improvement, estimated as the amount of difference between the pre- and posttest mean scores, belonged to the product-based and mentor-based groups, respectively. Moreover, the results testified to a conspicuous difference between the learners' degree of accuracy in writing tasks with differ- ent CCL, suggesting that the learners' accuracy in writing correlated negatively with the tasks' cognitive complexity level. In addition, as displayed in Table 1, the skewness and kurtosis values for all the date sets were fairly small and fell within the range of $+/-2$, implying the normality of the accuracy scores distribution on a descriptive level (Tabachnick \& Fidell, 2007).

Table 1. Descriptive statistics of the pretest and posttest accuracy scores in the three study groups

\begin{tabular}{|c|c|c|c|c|c|c|c|c|c|}
\hline CCL & Group & Variable & $\mathbf{N}$ & Minimum & Maximum & Mean & SD & Skewness & Kurtosis \\
\hline \multirow[t]{6}{*}{ High } & \multirow[t]{2}{*}{ Mentor-based } & Pretest scores & 20 & 0.493 & 0.661 & 0.588 & 0.044 & -0.404 & -0.226 \\
\hline & & Posttest scores & 20 & 0.543 & 0.705 & 0.621 & 0.047 & -0.035 & -1.007 \\
\hline & \multirow[t]{2}{*}{ Product-based } & Pretest scores & 20 & 0.454 & 0.694 & 0.603 & 0.059 & -0.868 & 0.569 \\
\hline & & Posttest scores & 20 & 0.532 & 0.749 & 0.641 & 0.057 & -0.124 & -0.612 \\
\hline & \multirow[t]{2}{*}{ Process-based } & Pretest scores & 20 & 0.421 & 0.691 & 0.596 & 0.066 & -0.870 & 1.043 \\
\hline & & Posttest scores & 20 & 0.454 & 0.694 & 0.600 & 0.061 & -0.418 & 0.322 \\
\hline \multirow[t]{6}{*}{ Moderate } & \multirow[t]{2}{*}{ Mentor-based } & Pretest scores & 20 & 0.533 & 0.783 & 0.655 & 0.076 & 0.115 & -1.083 \\
\hline & & Posttest scores & 20 & 0.543 & 0.800 & 0.674 & 0.077 & 0.000 & -1.044 \\
\hline & \multirow[t]{2}{*}{ Product-based } & Pretest scores & 20 & 0.560 & 0.800 & 0.688 & 0.063 & -0.300 & 0.140 \\
\hline & & Posttest scores & 20 & 0.596 & 0.821 & 0.705 & 0.058 & -0.152 & 0.071 \\
\hline & \multirow[t]{2}{*}{ Process-based } & Pretest scores & 20 & 0.533 & 0.800 & 0.669 & 0.064 & -0.056 & 0.005 \\
\hline & & Posttest scores & 20 & 0.560 & 0.800 & 0.672 & 0.062 & 0.368 & 0.273 \\
\hline \multirow[t]{6}{*}{ Low } & \multirow[t]{2}{*}{ Mentor-based } & Pretest scores & 20 & 0.500 & 0.800 & 0.658 & 0.073 & -0.313 & -0.146 \\
\hline & & Posttest scores & 20 & 0.571 & 0.800 & 0.689 & 0.066 & -0.062 & -0.926 \\
\hline & \multirow[t]{2}{*}{ Product-based } & Pretest scores & 20 & 0.571 & 0.846 & 0.696 & 0.063 & 0.040 & 1.068 \\
\hline & & Posttest scores & 20 & 0.603 & 0.857 & 0.725 & 0.065 & 0.103 & -0.048 \\
\hline & \multirow[t]{2}{*}{ Process-based } & Pretest scores & 20 & 0.543 & 0.818 & 0.688 & 0.063 & -0.161 & 0.647 \\
\hline & & Posttest scores & 20 & 0.562 & 0.821 & 0.697 & 0.061 & -0.382 & 0.076 \\
\hline
\end{tabular}

Min=Minimum, Max=Maximum, $\mathrm{SD}=$ Standard deviation

Table 2. Descriptive statistics of the pre- and posttest fluency scores in the three study groups

\begin{tabular}{|c|c|c|c|c|c|c|c|c|c|}
\hline CCL & Group & Variable & $\mathbf{N}$ & Minimum & Maximum & Mean & SD & Skewness & Kurtosis \\
\hline \multirow[t]{6}{*}{ High } & \multirow[t]{2}{*}{ Mentor-based } & Pretest scores & 20 & 521 & 705 & 626.85 & 60.73 & -0.302 & -1.184 \\
\hline & & Posttest scores & 20 & 540 & 731 & 637.05 & 58.33 & -0.258 & -0.953 \\
\hline & \multirow[t]{2}{*}{ Product-based } & Pretest scores & 20 & 510 & 702 & 602.95 & 71.29 & 0.017 & -1.644 \\
\hline & & Posttest scores & 20 & 502 & 701 & 603.65 & 67.08 & 0.059 & -1.425 \\
\hline & \multirow[t]{2}{*}{ Process-based } & Pretest scores & 20 & 519 & 717 & 638.15 & 72.12 & -0.597 & -1.404 \\
\hline & & Posttest scores & 20 & 532 & 768 & 657.50 & 74.14 & -0.544 & -1.219 \\
\hline \multirow[t]{6}{*}{ Moderate } & \multirow[t]{2}{*}{ Mentor-based } & Pretest scores & 20 & 143 & 232 & 184.80 & 27.29 & -0.111 & -1.219 \\
\hline & & Posttest scores & 20 & 139 & 239 & 190.25 & 29.03 & -0.179 & -1.251 \\
\hline & \multirow[t]{2}{*}{ Product -based } & Pretest scores & 20 & 133 & 233 & 183.35 & 29.66 & -0.009 & -0.834 \\
\hline & & Posttest scores & 20 & 145 & 232 & 184.55 & 26.87 & 0.169 & -0.955 \\
\hline & \multirow[t]{2}{*}{ Process-based } & Pretest scores & 20 & 132 & 241 & 185.60 & 31.71 & 0.116 & -0.728 \\
\hline & & Posttest scores & 20 & 143 & 244 & 195.35 & 29.27 & -0.033 & -0.566 \\
\hline \multirow[t]{6}{*}{ Low } & \multirow[t]{2}{*}{ Mentor-based } & Pretest scores & 20 & 284 & 378 & 321.80 & 24.42 & 0.911 & 0.226 \\
\hline & & Posttest scores & 20 & 299 & 389 & 328.80 & 21.49 & 1.335 & 1.869 \\
\hline & \multirow[t]{2}{*}{ Product -based } & Pretest scores & 20 & 288 & 361 & 320.70 & 23.05 & 0.528 & -0.772 \\
\hline & & Posttest scores & 20 & 265 & 369 & 319.30 & 25.96 & 0.074 & 0.060 \\
\hline & \multirow[t]{2}{*}{ Process-based } & Pretest scores & 20 & 273 & 385 & 335.50 & 32.03 & -0.130 & -0.997 \\
\hline & & Posttest scores & 20 & 292 & 389 & 348.85 & 28.43 & -0.409 & -0.718 \\
\hline
\end{tabular}

Min $=$ Minimum, Max $=$ Maximum, $\mathrm{SD}=$ Standard deviation 
As displayed in Table 2, the kurtosis and skewness values of the participants' fluency scores on all the pre- and posttest measures were well within the range of \pm 2 , indicating normality of the data's distribution in the three groups. With respect to all three levels of cognitive complexity, the pretest fluency scores improved from the pretest to the posttest measures in the process-based and mentor-based groups; however, the difference between the pretest and the posttest mean scores seemed to be inconspicuous regarding the product-based group. It is worth mentioning that the difference in fluency scores between the three CCL is completely acceptable, inasmuch as tasks with different CCL required the learners to produce texts in different time spans and with different word limits.

\section{Inferential Statistics}

As the chief inquiry, the study was intended to investigate whether adopting mentor text modeling approach would simultaneously enhance EFL learners' accuracy and fluency in writing. Accordingly, the correlation between the learners' fluency and accuracy scores was estimated and compared with the similar amounts in the other two groups.

Before performing the analysis, however, normality of the scores was investigated by the significance value of Shapiro-Wilk test and it was ensured that the distribution of all the data sets met the assumption of normality (see Table A1 in the Appendix). In addition, linearity, outliers, and homoscedasticity were checked through scatter plots illustrating the relationship between the accuracy and fluency scores in different groups (see Figures A1 to A18 in the Appendix).

Tables 3 and 4, respectively, report the Pearson product-moment correlation coefficients between the accuracy and fluency in writing tasks with high, moderate, and low CCL scores before (the pretest scores) and after (the posttest scores) the study course.

As the results for high CCL in Table 3 show, negative correlation was found between the accuracy and fluency pretest scores in the mentor-based $(r=-.127)$, product-based $(r=-.485, p<.05)$, and process-based $(r=-.314)$ groups. That is, although the learners' initial fluency and accuracy achievements correlated negatively with each other in all three groups of the study, the only significant correlation was observed in the product-based group. Regarding moderate CCL, there was a negative, however statistically non-significant, correlation between the fluency and accuracy pretest scores in all three groups of the study (Mentor-based: $r=-.109$, Product-based: $r=-.117$, and Process-based: $r=-.082)$. Considering Low CCL, as displayed in Table 3, the pretest accuracy scores correlated negatively, however non-significantly, with the pretest fluency scores in all three groups of the study (Mentor-based: $r=-.031$, Product-based: $r=-.051$, and Process-based: $r=-.183)$. In sum, the results in Table 3 implied a negative relationship between the learners' initial fluency and accuracy in writing tasks with different CCL.

According to the results in Table 4, there was a significant negative correlation between accuracy and fluency in the product-based group $(r=-.575, p<.01)$ for writing tasks with high CCL. The correlation between accuracy and
Table 3. Correlation coefficients between the pretest accuracy and fluency scores

\begin{tabular}{|c|c|c|c|}
\hline CCL & Group & Statistics & Values \\
\hline \multirow[t]{3}{*}{ High } & Mentor-based & $\begin{array}{l}\text { Pearson correlation } \\
\text { Sig. (2-tailed) } \\
\text { N }\end{array}$ & $\begin{array}{c}-0.127 \\
0.593 \\
20\end{array}$ \\
\hline & Product-based & $\begin{array}{l}\text { Pearson correlation } \\
\text { Sig. (2-tailed) } \\
\text { N }\end{array}$ & $\begin{array}{c}-0.485^{*} \\
0.030 \\
20\end{array}$ \\
\hline & Process-based & $\begin{array}{l}\text { Pearson correlation } \\
\text { Sig. (2-tailed) } \\
\text { N }\end{array}$ & $\begin{array}{c}-0.314 \\
0.178 \\
20\end{array}$ \\
\hline \multirow[t]{3}{*}{ Moderate } & Mentor-based & $\begin{array}{l}\text { Pearson correlation } \\
\text { Sig. (2-tailed) } \\
\text { N }\end{array}$ & $\begin{array}{c}-0.109 \\
0.645 \\
20\end{array}$ \\
\hline & Product-based & $\begin{array}{l}\text { Pearson correlation } \\
\text { Sig. (2-tailed) } \\
\text { N }\end{array}$ & $\begin{array}{c}-0.117 \\
0.624 \\
20\end{array}$ \\
\hline & Process-based & $\begin{array}{l}\text { Pearson correlation } \\
\text { Sig. (2-tailed) } \\
\text { N }\end{array}$ & $\begin{array}{c}-0.082 \\
0.730 \\
20\end{array}$ \\
\hline \multirow[t]{3}{*}{ Low } & Mentor-based & $\begin{array}{l}\text { Pearson correlation } \\
\text { Sig. (2-tailed) } \\
\text { N }\end{array}$ & $\begin{array}{c}-0.031 \\
0.897 \\
20\end{array}$ \\
\hline & Product-based & $\begin{array}{l}\text { Pearson correlation } \\
\text { Sig. (2-tailed) } \\
\text { N }\end{array}$ & $\begin{array}{c}-0.051 \\
0.830 \\
20\end{array}$ \\
\hline & Process-based & $\begin{array}{l}\text { Pearson correlation } \\
\text { Sig. (2-tailed) } \\
\text { N }\end{array}$ & $\begin{array}{c}-0.183 \\
0.440 \\
20\end{array}$ \\
\hline
\end{tabular}

*Correlation is significant at the 0.05 level (2-tailed)

fluency posttest scores were found to be significantly negative in the process-based group as well $(r=-.452, p<.05)$. According to Cohen's guidelines (1988, cited in Pallant, 2007, p. 132), the correlations of 0.50 and above are considered as large. Therefore, the correlation between the two variables was estimated to be fairly large in the product- and process-based groups. Nevertheless, the relationship between the accuracy and fluency posttest scores was found to be positive in the mentor-based group $(r=.288)$. However, the correlation was not found to be statistically significant.

With respect moderate CCL, notwithstanding the negative correlation between accuracy and fluency in the product-based ( $r=-.373)$ and process-based $(r=-.358)$ groups, there was a positive correlation between the mentioned variables in the mentor-based group $(r=.394)$. Nevertheless, none of the aforesaid relationships gained statistical significance.

Similar analysis on the accuracy and fluency posttest scores for writing tasks with low CCL indicated a significant positive correlation between the accuracy and fluency scores in the mentor-based group $(r=.446, p<.05)$. On the contrary, the accuracy and fluency posttest scores correlated negatively with each other in the product-based $(r=-.366)$ and process-based $(r=-.284)$ groups. It is worth mentioning that however the negative correlation between the two variables was found to be stronger in the product-based group in 
Table 4. Correlation coefficients between the posttest accuracy and fluency scores

\begin{tabular}{|c|c|c|c|}
\hline CCL & Group & Statistics & Values \\
\hline \multirow[t]{9}{*}{ High } & \multirow{3}{*}{ Mentor-based } & Pearson correlation & 0.288 \\
\hline & & Sig. (2-tailed) & 0.222 \\
\hline & & $\mathrm{N}$ & 20 \\
\hline & \multirow[t]{3}{*}{ Product-based } & Pearson correlation & $-0.575 * *$ \\
\hline & & Sig. (2-tailed) & 0.008 \\
\hline & & $\mathrm{N}$ & 20 \\
\hline & \multirow[t]{3}{*}{ Process-based } & Pearson correlation & $-0.452 *$ \\
\hline & & Sig. (2-tailed) & 0.045 \\
\hline & & $\mathrm{N}$ & 20 \\
\hline \multirow[t]{9}{*}{ Moderate } & \multirow[t]{3}{*}{ Mentor-based } & Pearson correlation & 0.394 \\
\hline & & Sig. (2-tailed) & 0.085 \\
\hline & & $\mathrm{N}$ & 20 \\
\hline & \multirow[t]{3}{*}{ Product-based } & Pearson correlation & -0.373 \\
\hline & & Sig. (2-tailed) & 0.105 \\
\hline & & $\mathrm{N}$ & 20 \\
\hline & \multirow[t]{3}{*}{ Process-based } & Pearson correlation & -0.358 \\
\hline & & Sig. (2-tailed) & 0.121 \\
\hline & & $\mathrm{N}$ & 20 \\
\hline \multirow[t]{9}{*}{ Low } & \multirow[t]{3}{*}{ Mentor-based } & Pearson correlation & $0.446^{*}$ \\
\hline & & Sig. (2-tailed) & 0.048 \\
\hline & & $\mathrm{N}$ & 20 \\
\hline & \multirow[t]{3}{*}{ Product-based } & Pearson correlation & -0.366 \\
\hline & & Sig. (2-tailed) & 0.113 \\
\hline & & $\mathrm{N}$ & 20 \\
\hline & \multirow[t]{3}{*}{ Process-based } & Pearson correlation & -0.284 \\
\hline & & Sig. (2-tailed) & 0.225 \\
\hline & & $\mathrm{N}$ & 20 \\
\hline
\end{tabular}

**Correlation is significant at the 0.01 level (2-tailed),

*Correlation is significant at the 0.05 level (2-tailed).

comparison with the process-based group, none of the two relationships was statistically significant assuming.05 as the specified level of significance.

In conclusion, the results in Tables 3 and 4 revealed that the negative correlation between the learners' initial levels of accuracy and fluency kept recurring after receiving either process-based or product-based writing instruction. Nonetheless, the primary negative relationship between accuracy and fluency in writing tasks with different CCL was turning positively after receiving writing instruction based on mentor text modeling. In other words, notwithstanding the product-based and process-based approaches, mentor text modeling contributed to the simultaneous development of accuracy and fluency reducing the trade-off effect between them for writing tasks with high, moderate, and low levels of cognitive complexity. Consequently, the results revealed that mentor text modeling naturalized the trade-off effect between accuracy and fluency in writing, regardless of the writing tasks' level of cognitive complexity.

\section{Discussion}

The trade-off effect found between accuracy and fluency (in the absence of mentor text modeling) lend supplemen- tary support to many previous studies which explored the trade-off effect between accuracy and fluency in writing and suggested that a higher performance in one linguistic component corresponds to lower performance in another (e.g., Ahmadian \& Tavakoli, 2011; Michel et al., 2007; Yuan \& Ellis, 2003). Developing a dichotomy between process-based and product-based classrooms in the L2 pedagogy, Reid (2001) concluded that the process teachers neglected accuracy in favor of fluency encouraging students to use their internal resources, whereas the product teachers focused solely on accuracy, appropriate rhetorical discourse and linguistic patterns to the exclusion of writing processes. The finding also supported the Skehan's (2009) trade-off hypothesis speculating that since attentional capacity is limited, attending to one performance area may take attention away from the others.

A more detailed evaluation of the correlation coefficients representing the relationship between accuracy and fluency for writing tasks with different CCL suggested that the negative correlation between these two components of L2 writing (i.e., accuracy and fluency) was increased as a result of raising cognitive complexity level of the writing tasks. This finding supported the Skehan's (1998) limited capacity hypothesis speculating that accuracy increases while complexity decreases due to learners' inability to pay attention to multiple processes simultaneously when many cognitive tasks are required. Moreover, in agreement with Robinson's (2001) claim that improvements in complexity and accuracy have little relationship with that of fluency in L2 productions, the findings of the current study indicated that accuracy and fluency developed in different directions as a result of employing either product-based or process-based instruction.

The efficacy of mentor text modeling in neutralizing the trade-off effect between accuracy and fluency would be endorsed conducting a brief review of the stages involved in implementing writing instruction based on such an approach. Taking the whole process into account, it can be easily inferred that although the stage of modeling and independent writing would be considered as the shared feature between mentor text modeling and product-based approach, collaborative writing and joint construction of the texts might be functioned as the common process between mentor text modeling and process-based approach. Detailed deconstruction of the mentor text, however, was the stage distinguished between mentor text modeling and the other two approaches. This distinguishing factor would be assumed as the factor which changed the passive role of the model texts in product-based approach-models for learners' occasional references - to the active role mentor texts played in enhancing the learners' writing proficiency-main scaffolding of requested tasks. Through mentor text modeling, therefore, the learners may have utilized a number of metacognitive strategies underlying the process approach, as well as exploiting the well-structured texts to develop a clear concept of a successful writing. Additionally, deconstructing the mentor text, through teacher modeling, provided students opportunities to recognize and discuss how authors use language, rhetoric, statistics, and data to support claims and arguments. This way learners could envisage the overall 
structure of the target texts they were supposed to write and, as a result, became more accurate and fluent writers at the same time.

Another possible explanation for capability of mentor text modeling approach in neutralizing the trade-off effect between accuracy and fluency would be attributed to the nature of mentor texts acting as structured frameworks for teaching EFL learners how to write a particular type of text. In fact, devoting several writing sessions as well as planning various meaningful activities to detailed analysis of well-structured texts which are broadly validated by experts in terms of different linguistic components, such as accuracy and fluency, would help the learners follow a gradual development in their writing competence. Having examined the ideal responses to the writing tasks in terms of grammatical accuracy and fluency, the learners in the mentor-based group were instructed in effective writing focusing on various factors contributing to grammatical accuracy, as well as receiving teacher-led instruction on how to adequately convey their ideas concerning any given topic.

The capability of mentor text modeling approach to affect both accuracy and fluency in writing positively, as revealed in the current study, is in agreement with the suggestion made by Escobar Alméciga and Evans (2014) based on a pedagogical experience of seeking for a methodology intended to increase academic writing proficiency. Using mentor texts and coding academic writing structures, the study suggested that mentor texts and the coding of academic writing structures can have a positive impact on the production of students' academic writing. To justify the finding, the researchers admitted to Corden (2007) that providing students with explicit models of good writing while encouraging observation, engagement, and assimilation of linguistic patterns, on the one hand, and guiding a strategic analysis about the language patterns which enriched high quality writings, on the other, may promote metacognitive awareness of the text dynamics examined in such writing improving the language choices made by the learners as they construct their own texts. Taking the definition provided by Escobar Alméciga and Evans (2014) for writing proficiency into consideration, one can easily deduce the links between his study outcome and that of the current study. Assuming the writing performance as the learners' writing achievements while attempting to produce written discourse which complies with the standards and conventions within a specific scholarly community (Alméciga and Evans, 2014), it can be inferred that a combination of all L2 components contributing to writing skill including both accuracy and fluency could be regarded in Escobar Alméciga and Evans's (2014) study.

Graham and Perin's (2007) point of view about an effective type of writing instruction may also shed light on the current study's finding. believing that an effective writing instruction should emphasize attention to task, purpose and audience as well as application of revision and editing to improve writing, they asserted that "as students repeatedly analyze models of good writing and attempt to emulate them, it is assumed that they develop a better understanding of the criteria underlying good writing" (Graham and Perin, 2007, p.36). It seems that the aforesaid feature can be well addressed through the use of mentor texts, inasmuch as the close reading inherent in the use of mentor texts would enable readers to critically analyze the author's intended meaning which provides opportunity to study the "writing moves" the author has made to communicate his/her message (i.e., word choice, sentence structures, use of literary devices, description that shows rather than tells, etc.)

Finally, the efficacy of mentor-text modeling in neutralizing the trade-off effect between accuracy and fluency can implicitly be justified taking the concluding remarks drawn from Kane's (2012) study into consideration. Having examined the impact of a mentor text inquiry approach to narrative writing instruction on attitude, self-efficacy, and writing processes of fourth grade students in an urban elementary school, she concluded that mentor text inquiry approach increases writing fluency, improves attention to language conventions, increases quantity of content, and improves organization and structure.

\section{CONCLUSION}

After a deep examination of the three approaches under investigation, the results revealed that contrary to the two traditional approaches to teaching writing (i.e., process-based and product-based) which enhanced either accuracy or fluency at the expense of the other, mentor text modeling affected both accuracy and fluency positively. The study also came to a conclusion that the efficacy of mentor text modeling in simultaneous development of accuracy and fluency was not dependent on the writing tasks' level of cognitive complexity. Given the study findings enumerated above mentor text modeling could be considered as an effective approach to neutralize trade-off effect between accuracy and fluency in writing, regardless of writing tasks' level of cognitive complexity.

Incorporate both process and product insights into an alternative instructional and curricular approach called mentor text modeling may have several pedagogical implications in EFL writing classrooms. Firstly, such a complementary use of both product and process approaches would help students develop cognitive skills while involving in analysis of mentor texts. At the same time, the approach might enhance students' metacognitive skills such as critical thinking and problem solving while engaging them in various pre-writing activities. This balanced emphasis on developing both cognitive and metacognitive abilities may pave the way for simultaneous increase in accuracy and fluency in writing. Additionally, the second finding of the study which revealed that the capability of mentor text modeling to simultaneously develop accuracy and fluency was not dependent on writing tasks' cognitive complexity levels may urge EFL teachers to adopt such an approach to teaching writing tasks with various cognitive demands in terms of complexity. Moreover, syllabus designers can exploit mentor texts in order to enrich syllabuses for writing courses.

It is worth noting that a number of limitations and delimitations such as limited size of the study sample, fairly short length of the training sessions, and employment of particular measures to gage accuracy and fluency in writing may 
inevitably limit the degree to which generalizations can be drawn from the data. Accordingly, the findings demand more verification carrying out more large-scale research in different foreign language learning. To further expand the study's findings, more studies on evaluating the effectiveness of mentor text modeling approach should be conducted in other ESL or EFL settings focusing on various writing tasks and allotting longer period of time to implement the intervention.

\section{REFERENCES}

Ahmadian, M.J., \& Tavakoli, M. (2011). The effects of simultaneous use of careful online planning and task repetition on accuracy, fluency, and complexity of EFL learners' oral production. Language Teaching Research, $15,35-59$.

Al-Haq, F., \& Al-Sobh, M. (2010). The effect of a web-based instructional EFL program on enhancing the performance of Jordanian secondary students. The JALT CALL Journal, 6(3), 189-218.

Balakrishnan, M. S. (2010). Writing case: The difference from a case study research methodology and a teaching study. Oxford: Oxford University Press.

Bloom B. S. (1956). Taxonomy of Educational Objectives, Handbook I: The Cognitive Domain. New York: David McKay Co Inc.

Bloom, B.S. (2001). Taxonomy of educational objectives and writing intended learning outcomes statements. International Assembly for Collegiate Business Education (IACBE), USA.

Bogard, J., and Mackin, M. (2015). Writing Is Magic, or Is It? Using Mentor Text to Develop the Writer's Craft. CA: Teacher created Materials Publishing.

Corden, R. (2007). Developing reading-writing connections: The impact of explicit instruction of literary devices on the quality of children's narrative writing. Journal of Research in Childhood Education, 21(3), 269-289.

Deane, P., Odendahl, N., Quinla, T., Fowles, M.,Welsh, C., Bivens-Tatum, J. (2008). Cognitive models of writing: Writing proficiency as a complex integrated skill. Princeton: Educational Testing Service (ETS).

Dorftman L.R., and Cappelli, R. (2007). Mentor text: teaching writing through children's literature, K-6. Portland: Stenhouse publishers.

Ellis R., Yuan F. (2004). The effects of planning on fluency, complexity, and accuracy in second language narrative writing. Studies in Second Language Acquisition, 26, 5984 .

Ellis, R., \& Barkhuizen, G., (2005). Analyzing learner language. New York: Oxford University Press.

Escobar Alméciga, W. Y., \& Evans, R. (2014). Mentor texts and the coding of academic writing structures: A functional approach. HOW, A Colombian Journal for Teachers of English, 21(2), 94-111.

Gallagher, K., (2011). Write like this: teaching real-world writing through modeling and mentor texts to subscribe to Literacy links. Portland: Stenhouse publishers.

Geranpaye, A. (2003). A quick review of the English Quick Placement Test. University of Cambridge ESOL Exam- inations. Extract form Research Notes, 12, 8-10.

Graham, S., \& Perin, D. (2007). Writing Next: Effective strategies to improve writing ofadolescents in middle and high schools. New York: Carnegie Corporation of New York.

Hamp-Lyons, L., \& Mathias, S. P. (1994). Examining expert judgments of task difficulty on essay tests. Journal of Second Language Writing, 3, 49-68.

Hayes, J. R. \& Flower, L. S. (1980). Identifying the organization of writing processes. In L. W. Gregg, \& E. R. Steinberg (Eds.). Cognitive processes in writing (pp. 3-30). Hillsdale, N.J.: Lawrence Erlbaum Associates.

Hestenes, D. (2006). Modelling in Physics and Physics Education. Paper presented at the Modeling Theory of Science, Cognition and Instruction Proceedings conference: Arizona State University. USA.

Kane, C. M. K. (2012). Investigating the impact of a mentor text inquiry approach to narrative writing instruction on attitude, self-efficacy, and writing processes of fourth grade students in an urban elementary school. Unpublished doctoral thesis, San Diego State University, San Diego, Argentina.

Kuiken, F., \& Vedder, I. (2008). Cognitive task complexity and written output in Italian and French as a foreign language. Journal of Second Language Writing, 17, 48-60.

Larsen-Freeman, D., (2009). Adjusting expectations: The study of complexity, accuracy, and fluency in second language acquisition. Applied Linguistics, 30, 579-589.

Lynne, R., \& Cappelli, R. (2007). Mentor texts: teaching writing through children's literature, K-6. Portland: Stenhouse Publishers.

Meyers, A. (2009). Writing With Confidence. Writing Effective Sentences and Paragraphs. New York: Vango Publication.

Michel, M.C., Kuiken, F. and Vedder, I. (2007). Effects of Task Complexity and Task Condition on Dutch L2. International Review of Applied Linguistics, 45(3), 241-259.

Murray, D. (1972). Teaching Writing as a Process, not a Product. The Leaflet, 11-14.

Naoroji, D., (2012). Using Mentor Texts to Improve Student Writing. Created by PCG Education for the Maine Content Literacy Project October 2012. MCLP Common Core Writing Workshop.

Nordin, S. \& Mohammad, N. (2006). The best of two approaches: Process/genre-based approach to teaching writing. The English Teacher, 30, 75-85.

Nueva, J. C. (2016). Genre-based and process-based approaches to teaching news articles. Pertanika Journals, 24(1), 385-400.

Nunan, D. (1999). Second Language Teaching and Learning. Boston: Heinle \& Heinle.

Omaggio Hadley, A. (1993). Teaching language in context. Boston: Heinle \& Heinle.

Ortenburger, R. H. (2013). Mentor text: your personal teaching assistant. Content area literacy task force, 1(4), 1. Retrived from http://ekuwritingproject.org/uploads/5/2/4/0/5240502/febmentortext.pdf.

Pallant, J., (2007). SPSS Survival Manual $3^{\text {rd }}$ Edition. 
New York: McGra Hill, Open University Press.

Pincas, A. (1984). Writing in English. London: Mac Millan.

Polio, C. (2001). Research methodology in second language writing research: The case of text based studies. In T. Silva and P. K. Matsuda (Eds.), On Second Language Writing (pp. 91-115). Mahwah, NJ: Lawrence Erlbaum.

Pytash, K.E., \& Morgan, D.N. (2014). Preparing pre-service teachers to become teachers of writing: A 20-year review of research literature. English Education, 47(1), 6-37.

Rahman, M. (2011). Genre-based writing instruction: Implications in ESP classroom. English for Specific Purposes World, 11(33), 1-9.

Reid, J. M. (2001). The Cambridge guide to teaching English to speakers of other languages. In R. Cater \& D. Nunan (Eds.), Writing (pp. 23-33). Cambridge: Cambridge University Press.

Richards, J. and Renandya, W. (2002). Methodology in Language Teaching: An Anthology of Current Practice. Cambridge: Cambridge University Press.

Robinson, P. (2001). Task complexity, task difficulty, and task production: exploring interactions in a componential framework. Applied Linguistics, 22(1), 27-57.

Robinson, P. (2003). Attention and memory during SLA. In C. Doughty \& M. Long (Eds.), Handbook of second language acquisition (pp. 630-678). Oxford: Blackwell.

Robinson, P. (2007). Task complexity, theory of mind, and intentional reasoning: Effects on speech production, interaction, uptake and perceptions of task difficulty. International Review of Applied Linguistics, 45, 193-214.

Sakoda, N., (2007). The distinction between process based and product based approaches to teaching writing and its effects on classroom methodology. Hiroshima Universi- ty of Economics, 1141-1156. Retrieved from http://harp. lib.hiroshima-u.ac.jphuemetadata480.

Skehan, P. (1998). A cognitive approach to language learning. Oxford: Oxford University Press.

Skehan, P. (2009). Modelling second language performance: Integrating complexity, accuracy, fluency, and lexis. Applied Linguistics, 30(4), 510-532.

Sutikno, M.K. (2008). Responding to students' writing. (Teaching writing or assessing it?). Journal Pendidikan Penabur, 10(7), 51-59.

Tabachnick, B. G., \& Fidell, L. S., (2007). Using multivariate statistics. Boston: Pearson/Allyn \& Bacon.

Tangpermpoon, T. (2008). Integrated approaches to improve students writing skills for English major students. $A B A C$ Journal, 28(2), 1-9.

Torghabeh, R.A., Hashemi, M.R., \& Ahmadi, H, Sh. (2010). Writing through literature: a novel approach to EFL writing instruction. Iranian EFL Journal, 6(4), 7-23.

Webb, N. L. (1997). Criterion for alignment of expectations and assessments in mathematics and science education. Washington DC: Council of Chief State School Affairs.

White, R. (1988). Process and Product. In P. C. Robinson (Ed), Academic writing (pp. 4-16). London: Modern English Publications in association with The British Council.

Wolfe-Quintero, K., Inagaki, S., \& Kim, H.-Y. (1998). Second language development in writing: Measures of fluency, accuracy and complexity. Technical report 17. Manoa, Hawai'i US: University of Hawai'i Press.

Yuan, F., \& Ellis, R. (2003). The effects of pre-task planning and on-line planning on fluency, complexity and accuracy in L2 monologic oral production. Applied Linguistics, 24, 1-27. 


\section{APPENDIX}

\section{Assumption Checked for using Pearson Product-moment Correlation Coefficients}

Table A1. Tests of normality on the accuracy and fluency scores

\begin{tabular}{|c|c|c|c|c|c|}
\hline \multirow[t]{2}{*}{ Variable } & \multirow[t]{2}{*}{ Group } & \multirow[t]{2}{*}{ CCL } & \multicolumn{3}{|c|}{ Shapiro-Wilk } \\
\hline & & & Statistic & $d f$ & Sig. \\
\hline \multicolumn{6}{|l|}{ Pretest scores } \\
\hline \multirow[t]{9}{*}{ Accuracy } & Mentor-based & High & 0.975 & 20 & 0.850 \\
\hline & & Moderate & 0.953 & 20 & 0.423 \\
\hline & & Low & 0.972 & 20 & 0.793 \\
\hline & Product-based & High & 0.931 & 20 & 0.164 \\
\hline & & Moderate & 0.935 & 20 & 0.195 \\
\hline & & Low & 0.926 & 20 & 0.192 \\
\hline & Process-based & High & 0.938 & 20 & 0.217 \\
\hline & & Moderate & 0.968 & 20 & 0.717 \\
\hline & & Low & 0.970 & 20 & 0.754 \\
\hline \multirow[t]{9}{*}{ Fluency } & Mentor-based & High & 0.925 & 20 & 0.124 \\
\hline & & Moderate & 0.944 & 20 & 0.280 \\
\hline & & Low & 0.917 & 20 & 0.087 \\
\hline & Product-based & High & 0.913 & 20 & 0.067 \\
\hline & & Moderate & 0.967 & 20 & 0.695 \\
\hline & & Low & 0.917 & 20 & 0.086 \\
\hline & Process-based & High & 0.910 & 20 & 0.053 \\
\hline & & Moderate & 0.967 & 20 & 0.696 \\
\hline & & Low & 0.959 & 20 & 0.518 \\
\hline \multicolumn{6}{|c|}{ Posttest scores } \\
\hline \multirow[t]{9}{*}{ Accuracy } & Mentor-based & High & 0.970 & 20 & 0.753 \\
\hline & & Moderate & 0.961 & 20 & 0.558 \\
\hline & & Low & 0.953 & 20 & 0.420 \\
\hline & Product-based & High & 0.975 & 20 & 0.857 \\
\hline & & Moderate & 0.929 & 20 & 0.144 \\
\hline & & Low & 0.976 & 20 & 0.880 \\
\hline & Process-based & High & 0.966 & 20 & 0.669 \\
\hline & & Moderate & 0.965 & 20 & 0.658 \\
\hline & & Low & 0.956 & 20 & 0.463 \\
\hline \multirow[t]{9}{*}{ Fluency } & Mentor-based & High & 0.941 & 20 & 0.250 \\
\hline & & Moderate & 0.936 & 20 & 0.200 \\
\hline & & Low & 0.908 & 20 & 0.051 \\
\hline & Product-based & High & 0.975 & 20 & 0.857 \\
\hline & & Moderate & 0.953 & 20 & 0.417 \\
\hline & & Low & 0.972 & 20 & 0.790 \\
\hline & Process-based & High & 0.938 & 20 & 0.226 \\
\hline & & Moderate & 0.958 & 20 & 0.510 \\
\hline & & Low & 0.961 & 20 & 0.562 \\
\hline
\end{tabular}




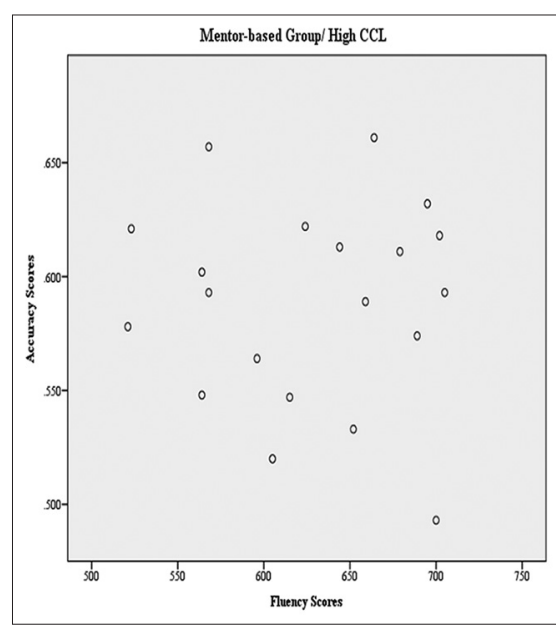

Figure A1. Relationship between the pretest accuracy and fluency scores in the mentor-based group

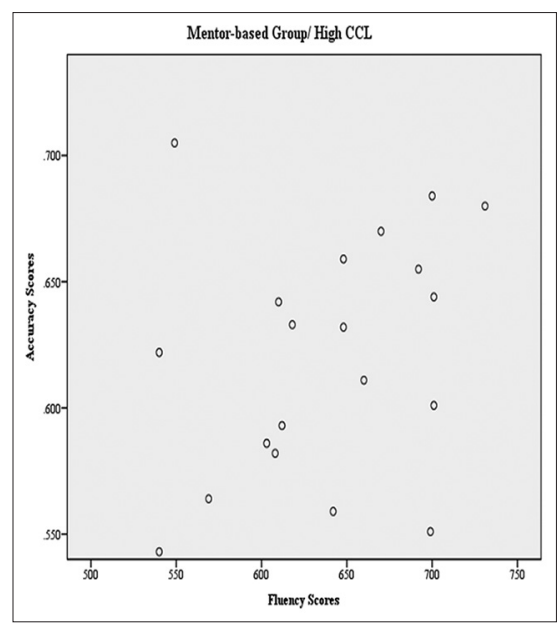

Figure A2. Relationship between the posttest accuracy and fluency scores in the mentor-based group

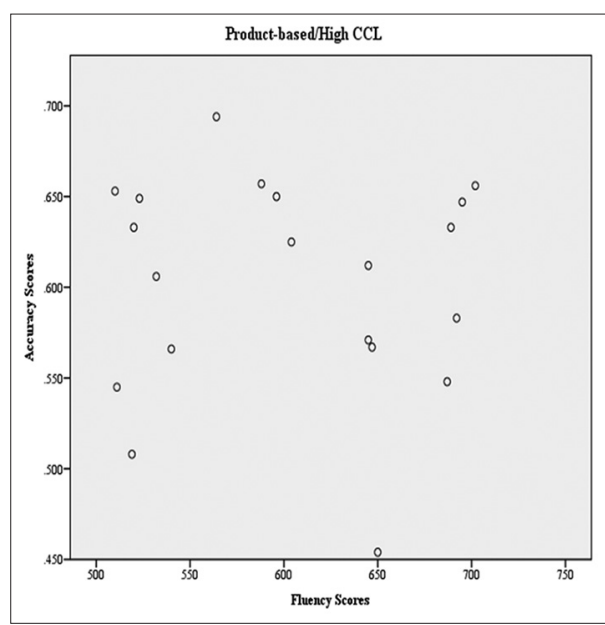

Figure A3. Relationship between the pretest accuracy and fluency scores in the product-based group

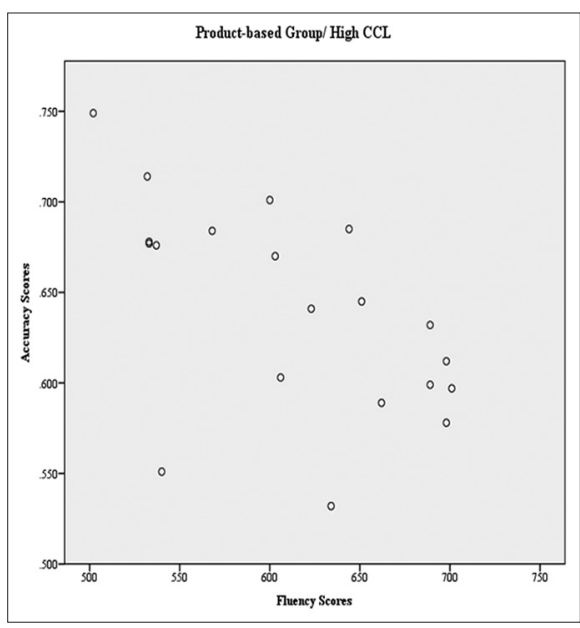

Figure A4. Relationship between the posttest accuracy and fluency scores in the product-based group

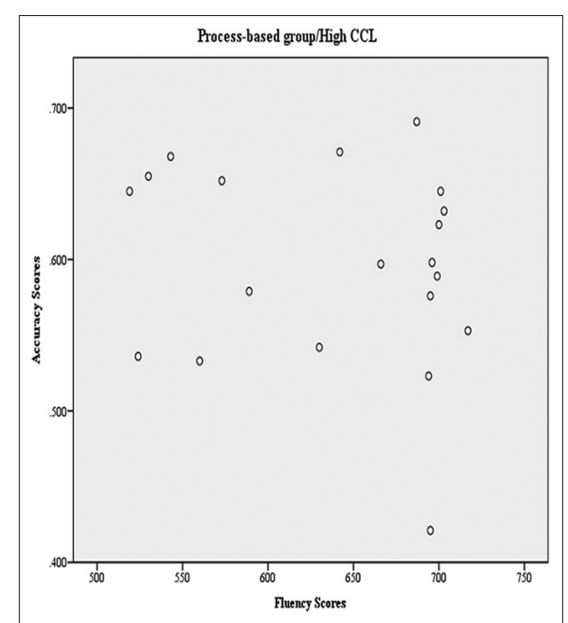

Figure A5. Relationship between the pretest accuracy and fluency scores in the process-based group

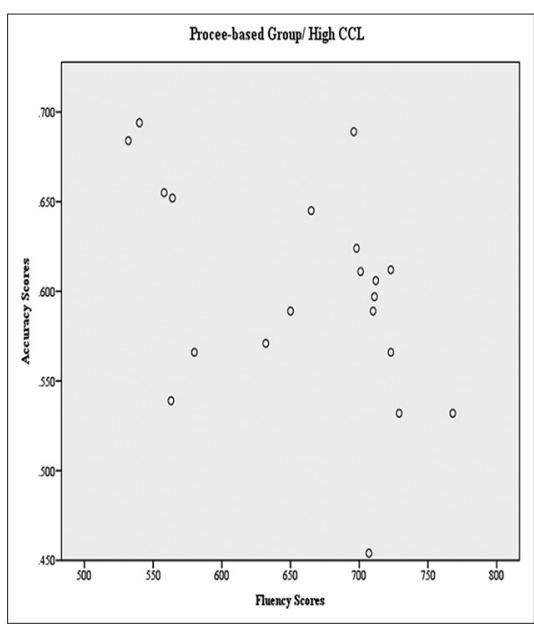

Figure A6. Relationship between the posttest accuracy and fluency scores in the process-based group 


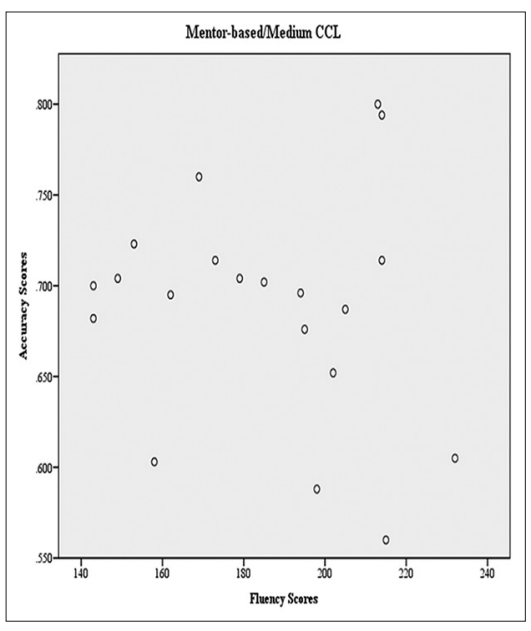

Figure A7. Relationship between the pretest accuracy and fluency scores in the mentor-based group

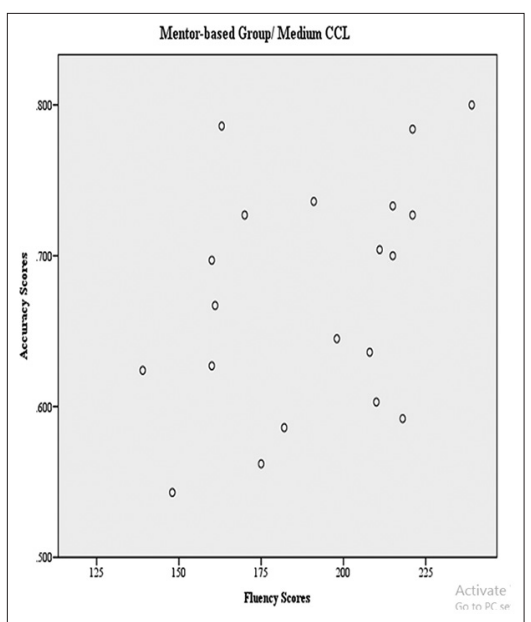

Figure A8. Relationship between the posttest accuracy and fluency scores in the mentor-based group

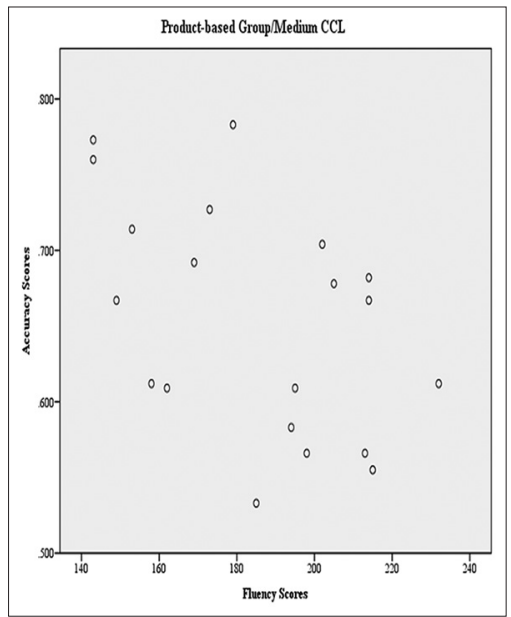

Figure A9. Relationship between the pretest accuracy and fluency scores in the product-based group

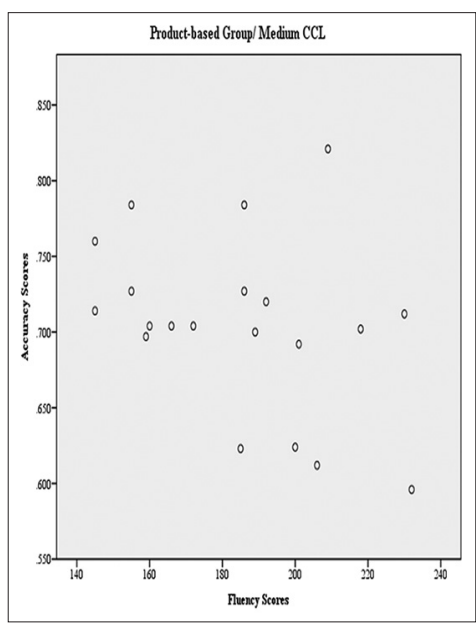

Figure A10. Relationship between the posttest accuracy and fluency scores in the product-based group

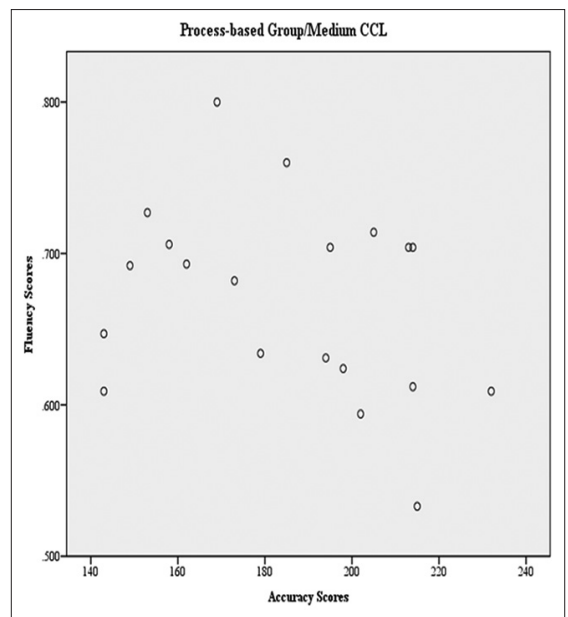

Figure A11. Relationship between the pretest accuracy and fluency scores in the process-based group

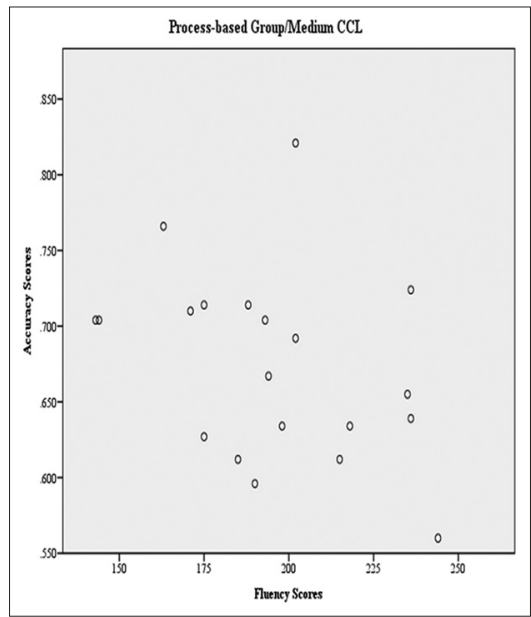

Figure A12. Relationship between the posttest accuracy and fluency scores in the process-based group 


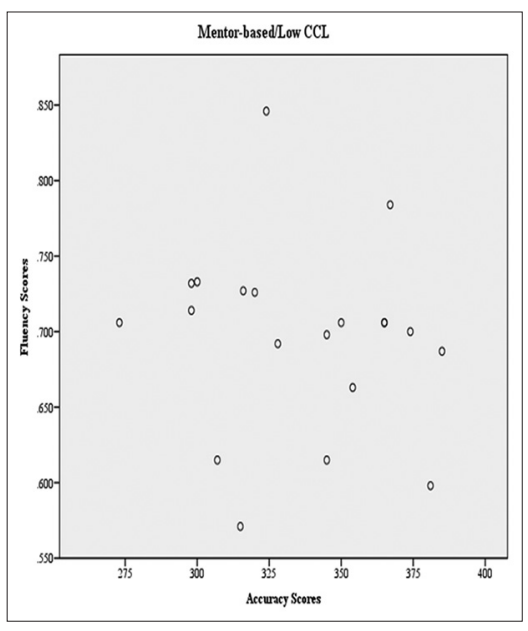

Figure A13. Relationship between the pretest accuracy and fluency scores in the mentor-based group

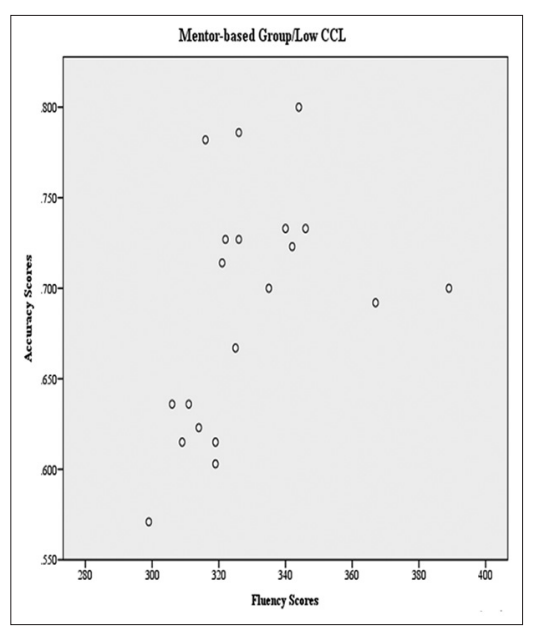

Figure A14. Relationship between the posttest accuracy and fluency scores in the mentor-based group

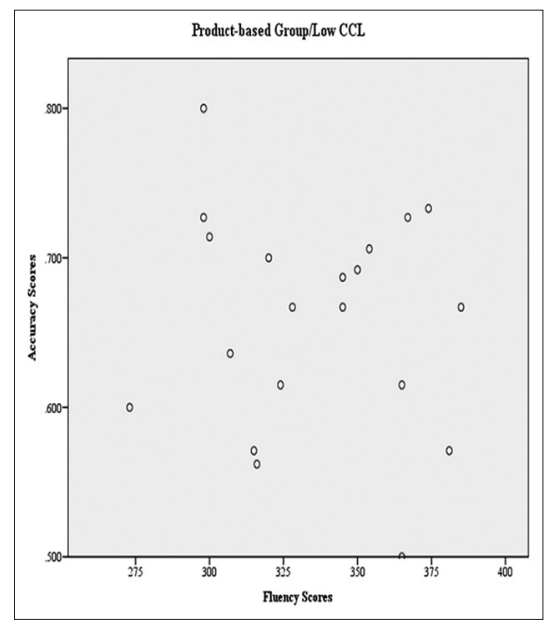

Figure A15. Relationship between the pretest accuracy and fluency scores in the product-based group

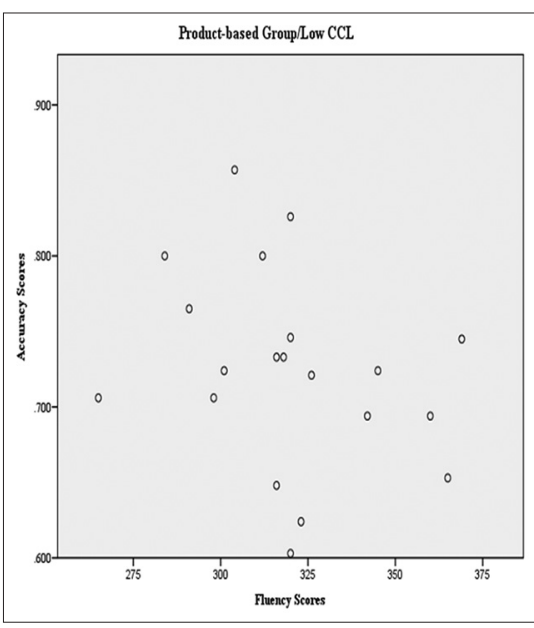

Figure A16. Relationship between the posttest accuracy and fluency scores in the product-based group

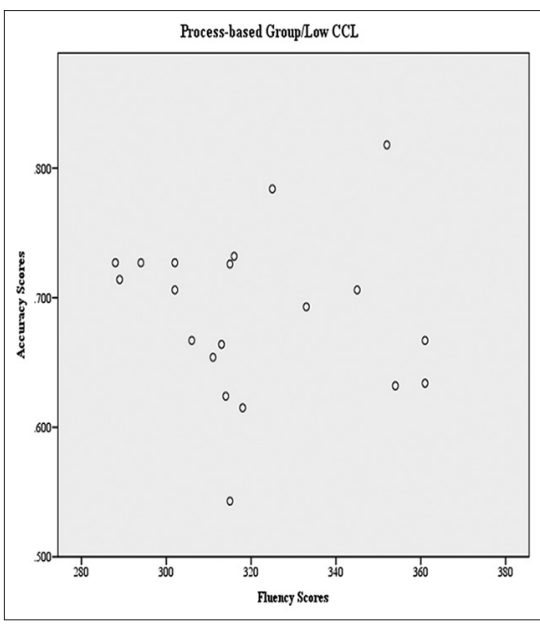

Figure A17. Relationship between the pretest accuracy and fluency scores in the process-based group

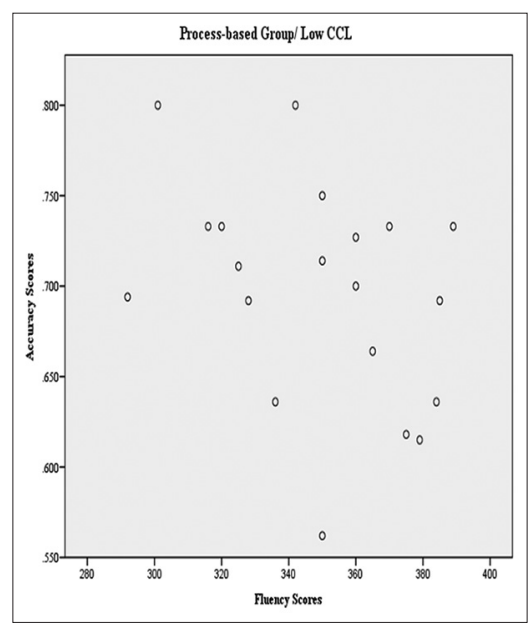

Figure A18. Relationship between the posttest accuracy and fluency scores in the process-based group 